\title{
A hidden intrusive complex below Somma-Vesuvius: insights from igneous xenoliths
}

\author{
B. CARIDDi ${ }^{1 *}$, V. GUARINO ${ }^{1}$, A. ZANETTI ${ }^{2}$, V. MORRA ${ }^{1}$,
} L. MELLUSO ${ }^{1}$

${ }^{1}$ DISTAR, Università degli Studi di Napoli Federico II, Complesso Universitario di Monte S.Angelo, Via Cintia 21, 80126 Napoli, Italy (*correspondence:

bruna.cariddi@unina.it) (vincenza.guarino@unina.it, vincenzo.morra@unina.it, leone.melluso@unina.it)

${ }^{2}$ Istituto di Geoscienze e Georisorse, sez. di Pavia-CNR, Via Ferrata 1, 27100 Pavia, Italy (alberto.zanetti@igg.cnr.it)

Xenoliths found in pyroclastic products of SommaVesuvius complex vary from clinopyroxenites through olivine-leucite monzogabbros (essexites-theralites) to alkali syenites and foidolites. Clinopyroxene is the main cumulus phase of the clinopyroxenites, biotite and olivine are less abundant. Plagioclase, clinopyroxene, leucite and olivine are the cumulus phases in the leucite monzogabbros with sodalite, nepheline and alkali feldspar as intercumulus phases. Syenites are composed by alkali feldspar, clinopyroxene, amphibole, biotite, leucite, sodalite, nepheline, melanite garnet and other accessory phases. Foidolites are made up of nepheline, haüyne, leucite, clinopyroxene, apatite and melanite. Interstitial glass and glass inclusions in clinopyroxenes are also found.

The major and LA-ICP-MS trace element composition of these phases, their position in the crystallization order indicate that these rocks are the product of crystallization and/or accumulus of the phases in the borders of the SommaVesuvius magma reservoirs. These reservoirs were filled by variably evolved magmas, ranging from basanites and leucite tephrites to phonolites, as also calculated from the liquids in equilibrium with the various cumulus crystals, from the mineral assemblages, and by matching the various mineral patterns with those already known in the literature on the Somma-Vesuvius rocks (e.g. [1, 2]).

The major and trace element zoning trends in clinopyroxene indicate the occurrence of a) recycling of phenocrysts before the cumulus process along the walls of the magma reservoirs and b) heterogeneous nucleation of pyroxenes, in response to interaction with thermometamorphic and skarn wall-rocks.

[1] Dallai, Cioni, Boschi, \& D'Oriano (2011), Earth and Planetary Science Letters 310, 84-95. [2] Scheibner, Wörner, Civetta, Stosch, Simon, \& Kronz (2007), Contributions to Mineralogy and Petrology 154, 55-74. 